\title{
The influence of some molluscicides on reproductive activity in
}

\section{rats}

\author{
S. S. Ibrahim*, A. Aboul-Ela, E. A. Mabrouk, K. Ali, G. A. Taha \\ Department of Physiology, Faculty of Veterinary Medicine, Beni-Suef University
}

\begin{abstract}
The present study is an endeavor for profound exploration about the effects of 2 commonly used molluscicides in Egypt (bayluscide and copper sulfate ) on some reproductive aspects in mature male Albino rats. For this purpose, 180 mature male Albino rats were used. Animals were equally divided into 3 groups; the $1^{\text {st }}$ group was considered as controls administered distilled water while those of the $2^{\text {nd }}$ and $3^{\text {rd }}$ groups were administered distilled water containing $1 / 20$ LD $_{50}$ of either baylucide or copper sulfate every 3 days for 8 successive weeks. The results of the present study revealed that administration of either molluscicides induced a serious drastic decline in the levels of the reproductive hormones; an effect which was not completely reversed after removal of the molluscicide for 8 successive weeks. This disruption upon reproductive hormones was concomitant with a significant deviation of semen parameters represented by a drop in the individual motility concomitant with an increase in dead sperm percentage as well as total sperm abnormalities. Moreover, stoppage of molluscicides administration along 8 successive weeks failed to improve all studied semen parameters. Moreover, evaluation of total antioxidant activity disclosed that application of either bayluscide or copper sulfate resulted in significant reduction in the total antioxidant capacity as compared with the corresponding control values; a finding which persisted after prevention of molluscicides administration along 8 weeks.
\end{abstract}

Molluscicides, also known as snail baits and snail pellets, are chemical compounds against molluscs, which are usually used in agriculture or gardening to control slugs and snails that can damage crops by feeding on them. In addition, they are widely used in Egypt and other developing countries for eradication of the snail species that serve as intermediate hosts for human disease schistosomiasis. This disease affects 200 millions people in tropical and subtropical countries and is considered as one of the important factors leading to disability among children in Africa (Takougang et al., 2006). In Egypt, beside treating the diseased people, one of the most effective and rapid means of reducing schistosomiasis transmission is snail control with molluscicides.

According to the World Health Organization (WHO, 1993), the desirable attributes of a molluscicide to be used in public health programs are the high activity and specificity for snails, the low toxicity to mammalian species, stability under different environmental and storage conditions, safety to the applicator and low cost. None of the synthetic molluscicides

* Corresponding author. Tel.: +2082 2322066;

Fax :+2 0822327982

E-mail address: ibrahim@bsu.edu.eg

(Shawki S. Ibrahim). currently available meet all these requirements and only one, the niclosamide (Bayluscide), is recommended by the WHO for large-scale use in schistosomiasis control.

Copper sulfate has been widely used as molluscicide, algaecide and fungicide. Besides being an effective molluscicide, copper sulfate is a material that has historically been used to control algae in swimming pools and fish ponds (Kamrin, 1997). According to US Environmental Protection Agency (EPA, 2008), copper sulfate can be corrosive to the skin and eyes. It is readily absorbed through the skin inducing a burning pain.

Despite of the widespread application of both molluscicides (bayluscide and copper sulfate), their drastic effects, as endocrine disruptors, upon reproduction are not clearly understood. Therefore, the current study was established to elicit a profound exploration about the influence of both molluscicides upon some reproductive aspects in mature male Albino rats.

Materials and methods

This study included 180 mature male Albino rats weighing $170-190 \mathrm{~g}$ obtained from Helwan Farm for the Laboratory Animals (Ministry of Health). Animals were transferred to the Physiology Department, Faculty of Veterinary Medicine, Beni Suef University where they were left for 2 weeks for acclimatization. Throughout 
the experimental period, rats were kept under constant hygienic conditions as well as offered food and water ad libitum.

Rats under experiment were equally divided into 3 groups (of 60 rats each; the rats of $1^{\text {st }}$ group (control) were administered distilled water, while those of the $2^{\text {nd }}$ and $3^{\text {rd }}$ groups were administered distilled water containing $1 /$ $20 \mathrm{LD}_{50}$ of either baylucide (Bayer Corp., Germany) or copper sulfate (El-Nasr Pharm. Chem. Co.). The administered dose was freshly prepared by dissolving it in $500 \mu 1$ distilled water and was given every 3 days to each animal through stomach tube for 8 successive weeks. This protocol of administration was previously outlined by WHO (1993); Adu and Egbunike, (2005), respectively.

Sample collection. At the end of the $8^{\text {th }}$ week, individual blood samples were collected from all groups (60 rats / group). The corresponding anterior pituitaries were separated and preserved in acetone for 3 days then weighed and ground in a mortar to be dissolved in phosphate buffer saline " PBS " of pH 6.8 at a rate of $1.0 \mathrm{mg}$ dry anterior pituitary / $\mathrm{ml}$ then placed in a sterile labeled vial. Sera and pituitaries, immediately after preparation were preserved in a deep freezer at $-20^{\circ} \mathrm{C}$ till the immunological assay of the studied hormones; gametogenic hormone (FSH), interstitial cell stimulating hormone (LH) and testosterone (T). Also, serum was used to determine the total antioxidant activity. In addition, corresponding individual semen samples were collected by maceration of epididymis and vasa deferentia to be used for semen evaluation (individual sperm motility, estimation of live / dead \% and abnormalities) as mentioned by Narayana et al., (2005).

At the end of the $8^{\text {th }}$ weak, administration of both molluscicides was prevented and the remaining animals (30/group) were allowed for normal drug withdrawal (recovery period) for another 8 weeks (one spermatogenic cycle).

Estimation of gonadotropins in pituitary and serum samples was performed by means of enzyme linked immunosorbent assay " ELISA " as outlined by Voller et al., (1979). Serum levels of $\mathrm{T}$ in the control and treated rats were assayed using the radioimmunoassay technique as described by Jaffe and Behrman, (1974). Determination of $\mathrm{T}$ levels was carried out in the Middle Eastern Regional Radioisotope Centre for the Arab Countries, Dokki, using the specific Kits of Diagnostic Products Corporation (Los
Angeles, USA). In addition, the serum antioxidant activity "AOA" was measured using the protocol described by Koracevic et al., (2001).

According to Beardeu and Fuqucy, (1980), progressive forward sperm motility was evaluated by microscopical examination of diluted semen. On the other side, Live/dead percentage of sperms was determined by using eosin nigrosine stain (Blom, 1950). The sperm cells abnormalities were determined by using alkaline methyl violet according to Blom, (1943). In this concern, sperm abnormalities were classified into primary (giant, dwarf and double head as well as double or coiled tail) and secondary (detached head, bent and/or wavy tail).

Throughout the experimental study, the obtained data were subjected to statistical analysis as outlined by Snedecor and Cochran, (1987) as well as SAS Program, (1994) to determine ANOVA.

\section{Results}

Pituitary and serum levels of FSH in controls and treated rats. It appears from Table 1 that pituitary content of the hormone among controls following 8 weeks of administration was $6.08 \pm$ 0.56 i.u. / mg dry weight; a value which showed significant decline in bayluscide and copper sulfate - treated groups $(2.42 \pm 0.19$ and $1.85 \pm$ 0.23 i.u. / mg dry weight, respectively. Similar pattern of decline was also recorded in the serum of bayluscide and copper sulfate - treated groups compared with the corresponding control group.

After recovery ( 8 weeks), the condition was improved without return to normal conditions as in bayluscide and copper sulfate - treated groups, pituitary and serum FSH levels remained lower than those of the corresponding control values.

Pituitary and serum levels of interstitial cell stimulating hormone in controls and molluscicides - treated rats. Following 8 weeks of administration, Table 2 showed that pituitary content of ICSH among controls was $3.14 \pm 0.26$ i.u. / mg dry weight; a value which showed significant decline in bayluscide and copper sulfate - treated groups $(1.44 \pm 0.16$ and $0.95 \pm$ 0.10 i.u. / mg dry weight, respectively). Similar pattern of ICSH drop was also recorded in the serum of bayluscide and copper sulfate - treated groups compared with the corresponding control group. 
Table (1): Pituitary (i.u. $/ \mathrm{mg}$ ) and serum (i.u. $/ \mathrm{ml}$ ) of gametogenic hormone levels (i.u) in control and treated rats (mean $\pm \mathrm{SE}$ ).

\begin{tabular}{lcccccc}
\hline \multirow{2}{*}{$\begin{array}{l}\text { Time of } \\
\text { sampling }\end{array}$} & \multicolumn{2}{c}{ Control } & \multicolumn{2}{c}{ Bayluscide } & \multicolumn{2}{c}{ Copper sulfate } \\
\cline { 2 - 6 } & $\begin{array}{c}\text { Pituitary } \\
\text { (i.u/mg) }\end{array}$ & $\begin{array}{c}\text { Serum } \\
(\mathrm{i} . \mathrm{u} / \mathrm{ml})\end{array}$ & $\begin{array}{c}\text { Pituitary } \\
(\mathrm{i} . \mathrm{u} / \mathrm{mg})\end{array}$ & $\begin{array}{c}\text { Serum } \\
(\mathrm{i} . \mathrm{u} / \mathrm{ml})\end{array}$ & $\begin{array}{c}\text { Pituitary } \\
(\mathrm{i} . \mathrm{u} / \mathrm{mg})\end{array}$ & $\begin{array}{c}\text { Serum } \\
\text { (i.u/ml) }\end{array}$ \\
\hline 8 weeks & $6.08 \pm 0.56$ & $3.96 \pm 0.41$ & $2.42 \pm 0.19^{*}$ & $2.07 \pm 0.17^{*}$ & $1.85 \pm 0.23^{*}$ & $1.79 \pm 0.15^{*}$ \\
16 weeks & $6.38 \pm 0.61$ & $3.81 \pm 0.39$ & $3.59 \pm 0.43^{*}$ & $2.69 \pm 0.35^{*}$ & $2.63 \pm 0.17^{*}$ & $1.98 \pm 0.23^{*}$ \\
\hline
\end{tabular}

SE : Standard error.

* : Significantly different from corresponding controls at $\mathrm{P} \leq 0.001$

Table (2): Pituitary and serum levels of interstitial cell stimulating hormone in controls and molluscicides - treated rats (Mean $\pm \mathrm{SE}$ ).

\begin{tabular}{lcccccc}
\hline \multirow{2}{*}{$\begin{array}{l}\text { Time of } \\
\text { sampling }\end{array}$} & \multicolumn{2}{c}{ Control } & \multicolumn{2}{c}{ Bayluscide } & \multicolumn{2}{c}{ Copper sulfate } \\
\cline { 2 - 7 } & $\begin{array}{c}\text { Pituitary } \\
(\mathrm{i} . \mathrm{u} / \mathrm{mg})\end{array}$ & $\begin{array}{c}\text { Serum } \\
(\mathrm{i} . \mathrm{u} / \mathrm{ml})\end{array}$ & $\begin{array}{c}\text { Pituitary } \\
(\mathrm{i} . \mathrm{u} / \mathrm{mg})\end{array}$ & $\begin{array}{c}\text { Serum } \\
(\mathrm{i} . \mathrm{u} / \mathrm{ml})\end{array}$ & $\begin{array}{c}\text { Pituitary } \\
(\mathrm{i} . \mathrm{u} / \mathrm{mg})\end{array}$ & $\begin{array}{c}\text { Serum } \\
(\mathrm{i} . \mathrm{u} / \mathrm{ml})\end{array}$ \\
\hline 8 weeks & $3.14 \pm 0.26$ & $2.06 \pm 0.17$ & $1.44 \pm 0.16^{*}$ & $1.02 \pm 0.08^{*}$ & $0.95 \pm 0.10^{*}$ & $0.59 \pm 0.07^{*}$ \\
16 weeks & $2.98 \pm 0.23$ & $2.12 \pm 0.14$ & $1.56 \pm 0.12^{*}$ & $0.98 \pm 0.11^{*}$ & $1.98 \pm 0.17^{*}$ & $1.11 \pm 0.13^{*}$ \\
\hline
\end{tabular}

SE: Standard error.

*: Significantly different from corresponding controls at $\mathrm{P} \leq 0.001$

Table (3): Serum testosterone levels ( $\mathrm{ng} / \mathrm{ml}$ ) in controls and treated rats (Mean $\pm \mathrm{SE}$ ).

\begin{tabular}{lccc}
\hline Time of sampling & Control & Bayluscide & Copper sulfate \\
\hline 8 weeks & $5.33 \pm 0.15$ & $0.5 \pm 0.17^{*}$ & $0.9 \pm 0.65^{*}$ \\
16 weeks & $5.64 \pm 0.19$ & $1.66 \pm 0.13^{*}$ & $1.75 \pm 0.15^{*}$ \\
\hline
\end{tabular}

SE : Standard error.

* : Significantly different from corresponding controls at $\mathrm{P} \leq 0.001$.

Table (4): Semen analysis of control and molluscicides - treated rats (Mean $\pm \mathrm{SE}$ ).

\begin{tabular}{lcccccc}
\hline \multirow{2}{*}{ Treatment } & \multicolumn{2}{c}{ Individual motility } & \multicolumn{2}{c}{ Live - dead \% } & \multicolumn{2}{c}{ Total sperm abnormalities } \\
\cline { 2 - 7 } & $\mathbf{8}$ weeks & $\mathbf{1 6}$ weeks & $\mathbf{8}$ weeks & $\mathbf{1 6}$ weeks & 8 weeks & 16 weeks \\
\hline Control & $71.4 \pm 0.22$ & $72.4 \pm 0.20$ & $83.5 \pm 0.20$ & $84.6 \pm 0.23$ & $13.6 \pm 0.20$ & $13.5 \pm 0.22$ \\
Bayluscide & $43.5 \pm 0.89^{*}$ & $55.2 \pm 0.20^{*}$ & $51.4 \pm 0.22^{*}$ & $63.1 \pm 0.20^{*}$ & $37.0 \pm 0.38^{*}$ & $30.1 \pm 0.15^{*}$ \\
Copper sulfate & $54.7 \pm 0.67^{*}$ & $59.8 \pm 0.27^{*}$ & $63.4 \pm 0.47^{*}$ & $70.2 \pm 0.30^{*}$ & $34.7 \pm 0.36^{*}$ & $28.2 \pm 0.15^{*}$ \\
\hline
\end{tabular}

SE : Standard error.

* : Significantly different from corresponding controls at $\mathrm{P} \leq 0.001$.

Table (5): Total antioxidant activity (Mmol. / L) of control and molluscicides - treated rats ( Mean $\pm \mathrm{SE})$.

\begin{tabular}{cccc}
\hline Time of sampling & Control & Bayluscide & Copper sulfate \\
\hline 8 weeks & $2.20 \pm 0.21$ & $0.30 \pm 0.12^{*}$ & $0.40 \pm 0.16^{*}$ \\
16 weeks & $2.40 \pm 0.24$ & $0.40 \pm 0.13^{*}$ & $0.60 \pm 0.15^{*}$ \\
\hline
\end{tabular}

\footnotetext{
SE : Standard error.

* : Significantly different from corresponding controls at $\mathrm{P} \leq 0.001$.
}

After recovery ( 8 weeks), the pituitary and serum hormone level did not show significant improvement in both treated groups as compared with the corresponding control values.

Serum testosterone " $T$ " levels in controls and treated rats. It appears from Table 3 that administration of both molluscicides for 8 weeks led to a significant decline in serum testosterone level in bayluscide and copper sulfate - treated groups $(0.5 \pm 0.17$ and $0.9 \pm 0.65 \mathrm{ng} / \mathrm{ml}$, respectively) as compared with controls (5.33 \pm $0.15 \mathrm{ng} / \mathrm{ml}$ ).

After recovery (8 weeks), the serum testosterone level did not show significant improvement in both treated groups as compared with the corresponding control values.

Evaluation of semen analysis in control and treated rats. It appears from table 4 that 
administration of both molluscicides induced a significant drop in the individual sperm motility concomitant with an increase in dead sperm percentage as well as total sperm abnormalities. Moreover, stoppage of molluscicides administration along 8 successive weeks failed to return all studied semen parameters to their control values.

Total antioxidant activity of control and treated rats. Data presented in table 5 displayed that application of either bayluscide or copper sulfate resulted in significant reduction in the total antioxidant activity as compared with the corresponding control values; a finding which persisted after prevention of molluscicides administration along 8 weeks.

\section{Discussion}

Regarding hazards associated with exposure to molluscicides upon reproduction, the majority of the previous studies focused mainly on the clinical manifestations without giving a meaningful explanation about their influence upon either gonadotropins and / or male sex steroids.

In the current study, the levels of the pituitary gonadotropins ( $\mathrm{FSH}$ and ICSH ) among control rats were $6.08 \pm 0.56$ and $3.14 \pm$ 0.26 i.u. / mg dry weight, respectively while the corresponding serum levels were $3.96 \pm 0.41$ and $2.06 \pm 0.17$ i.u. / $\mathrm{ml}$, respectively. On the other side, administration of either bayluscide or copper sulfate for 8 successive weeks resulted in a significant reduction of both hormones in the pituitary gland and serum as compared with the corresponding control values. Moreover, this profile of decreased pituitary and serum gonadotropins persisted even after stoppage of administeration; a finding which clarifies that stoppage of the studied molluscicides administration for 8 weeks was not sufficient to restore the normal hormonal profile of both gonadotropins. Similar findings were recorded for serum testosterone levels Therefore, it could be concluded that exposure of animals to the studied molluscicides has a harmful effect upon their reproductive performance displayed by remarkable drop of FSH, ICSH and T; an influence which persists even after removal of the molluscicides administration.

This conclusion for bayluscide receives a strong evidence from a series of previous reports done by EPA, (1999); Nettles et al., (2001); WHO, (2003). Moreover, the unapparent effect of bayluscide in some of these reports could be attributed to the administered dose rate, animal species, exposure time and route of administration. Regarding copper sulfate, Kamrin, (1997) found in rats that chronic exposure to low levels of copper sulfate leads to anemia accompanied with retarded growth rate and when animals were given dietary doses of $200 \mathrm{mg} / \mathrm{kg} /$ day they caused starvation and death. Moreover, sheep given oral doses of 20 $\mathrm{mg} / \mathrm{kg} /$ day showed blood cell and kidney damage with degenerative changes. In males, copper sulfate has been shown to cause reproductive effects in tested animals. Moreover, hypercuprosis in rams led to degenerative and necrotic effects in the seminiferous epithelium and spermatozoa cells (Gamcik et al., 1990; Vrzgulovi et al., 1995). Adu and Egbunike, (2005) reported that administration of copper sulphate in rabbit feeds induced no significant differences in paired testes weight, relative testes weight, testes density, testicular element and daily sperm production from gonadal sperm reserve. However, gonadal sperm reserves and daily sperm production by quantitative testicular histology were significantly lower in copper sulfate - treated group. Similarly, Pesch et al., (2006) reported that excessive copper intake had a negative effect on the reproductive organs of males and females.

Crisp et al., (1998); Leung (2006) considered different types of molluscicides as endocrine disruptors as they induced harmful effect upon reproductive hormones and consequently lead to infertility. The authors included molluscicides as endocrine disruptors as they are exogenous agents that interferes with synthesis, secretion, transport, binding, action, or elimination of hormones in the body which are responsible for maintenance of reproduction, development and / or behavior.

Molluscicides could be considered as stressors. In this respect, Acharya et al., (2008); Manna et al., (2008) found that stressors decreased enzymes responsible for steroidogenesis leading to reduce plasma testosterone level. The possible mechanisms through which both studied molluscicides affect reproductive performance may be referred to the effect on the process of uncoupling oxidative phosphorylation (Nettles et al., 2001).

The results of the current study revealed that molluscicides induced a significant drastic effect on all studied semen parameters, a finding which was previously documented in a series of 
studies. In this respect, Chulavatnatol, (1982) reported that the motility initiation of rat sperm, in vitro, was inhibited by copper ions. Moreover, Vega et al., (1988) recorded significant abnormal sperm morphology without any effect on sperm count or testis weight following administration of niclosamide " $60,80,100$ and $120 \mathrm{mg} / \mathrm{kg}$ b.wt". In addition, the authors suggested that the increase in abnormal sperms depends on the systemic presence of non-conjugated niclosamide metabolites. Adu and Egbunike, (2005) reported that administration of copper sulphate in rabbit feeds induced no effect on daily sperm production from gonadal sperm reserve. However, gonadal sperm reserves and daily sperm production by quantitative testicular histology were significantly lower in copper sulfate - treated group.

Table 5 reveals that application of either bayluscide or copper sulfate lead to significant reduction in the total antioxidant activity as compared with the corresponding control values; a finding which persisted after prevention of molluscicides administration along 8 weeks.

Molluscicides could be considered as stressors resulting in elevation of the serum level of reactive oxygen species "ROS" (WHO, 2003). Several mechanisms have been proposed to explain $\mathrm{Cu}$-induced cellular toxicity. Most often, the basis for these theories is the propensity of free $\mathrm{Cu}$ ions to participate in the formation of ROS. Both cupric and cuprous $\mathrm{Cu}$ ions can participate in oxidation and reduction reactions. In the presence of superoxide $\left({ }^{*} \mathrm{O}_{2}-\right)$ or reducing agents such as ascorbic acid or $\mathrm{GSH}, \mathrm{Cu}^{2+}$ can be reduced to $\mathrm{Cu}^{+}$, which is capable of catalyzing the formation of hydroxyl radicals $(\mathrm{OH} \sqrt{ })$ from hydrogen peroxide $\left(\mathrm{H}_{2} \mathrm{O}_{2}\right)$ via the Haber-Weiss reaction (Bremner, 1998).

\section{References}

Acharya, U. R.; Mishra, M.; Patro, J. and Panda, M. K. (2008): Effect of vitamins $C$ and $E$ on spermatogenesis in mice exposed to cadmium. Reprod. Toxico., $25: 84-88$.

Adu, A. O. and Egbunike, G.N. (2005): Spermatogenesis and daily sperm production of rabbits fed diets with different levels of copper sulphate. J. Agric. Forest. Soc. Sci., 3: $126-131$.

Beardeu, J. H. and Fuqucy, J. W. (1980): Applied Animal Reproduction. Rston publishing Co., INC. Reston, Virginia, USA.

Blom, E. A. (1943): New and Uncomplicated Method for Staining Bull Sperm. Skandivavick, Vet. Tidsker., 33 : 428 $-431$.

Blom, E.A. (1950): A simple staining method for the differentiation between live and dead cells by means of eosin and nigrosine stain. Vet. Med., 2: 58 - 64.

Bremner, I. (1998): Manifestations of copper excess. Am. J. Clin. Nutr., 67 : 1069 -1073.
Chulavatnatol, M. (1982): Motility initiation of quiescent spermatozoa from rat caudal epididymis: effects of $\mathrm{pH}$, viscosity, osmolality and inhibitors. Int. J. Androl., $4: 425-$ 436.

Crisp, T. M.; Clegg, E. D.; Cooper, R. L.; Wood, W. P.; Anderson, D. G.; Baeteke, K. P. et al., (1998): Environmental endocrine disruption: an effects assessment and analysis. Environ. Hlth. Perspect., $106: 11$ - 17.

EPA, (1999): Reregistration Eligibility Decision (RED). US Environmental Protection Agency Report. Office of Pesticide Programs, Bayluscide : 1 - 77.

EPA, (2008): US Environmental Protection Agency Report. Office of Pesticide Programs. Copper Facts : 1 - 23.

Gamcik, P.; Bires, J.; Vrzgula, L. and Mesaros, P. (1990): Effect of experimental intoxication with copper from industrial emission on reproductive ability in rams. Reprod. Don. Anim., 25: 235 - 241.

Jaffe, B. M. and Behrman, N.R. (1974): Methods of Hormone Radioimmunoassay. Academic Press, London.

Kamrin, M. A. (1997): Pesticide Profiles - Toxicity Environmental Impact, and Fate. CRC- Lewis Publishers, Boca Raton 829 FL.: 421-578.

Koracevic, D; Koracevic, G; Djordjevic, V; Andrejevic, $\mathrm{S}$ and Cosic, V. (2001): Method for the measurement of antioxidant activity in human fluids. J. Clin. Pathol., 54 : $356-361$.

Leung, P. C. K. (2006): Immunology, Endocrine And Metabolic Agents In Medicinal Chemistry. Volume 6 (1): 214 - 255., Bentham Science Publishers.

Manna, P.; Sinha, M. and Sil, P.C. (2008): Amelioration of cadmium-induced cardiac impairment by taurine. Chemico-Biol. Interact. 174: 88 - 97.

Narayana, K.; Prashanthi, N.; Nayanatara, A. Kumard, H.C.; Abhilash, K. et al., (2005): Effects of methyl parathion (o,o-dimethyl o-4-nitrophenyl phosphorothioate) on rat sperm morphology and sperm count, but not fertility, are associated with decreased ascorbic acid level in the testis. Mut. Res., $588: 28-34$.

Nettles, D. C.; Staats, N.R. and Chipman, B.D. (2001): Supplemental environmental Impact Statement. A longterm program of sea lamprey control in Lake Champlain. US Fish Wildlife Service, Vermont Department of Fish and Wildlife : 466 - 472.

Pesch, S.; Bergmann, M. and Bostedt, H. (2006): Determination of some enzymes and macro- and microelements in stallion seminal plasma and their correlations to semen quality. Theriogenol., 66: 307 - 313.

SAS Program (1994): SAS User Guide Statistics. SAS Inst. Carry, NC., USA.

Snedecor, G.W. and Cochran, W. (1987): Statistical Methods. 8 th Ed., Iowa State University Press, Ames Iowa, USA.

Takougang, I.; Meli, J. and Angwafo, F. (2006): Field trials of low dose bayluscide on snail hosts of schistosome and selected nontarget organisms in Sahelian, Cameroon. Mem. Osw. Cruz., 101 ( 4 ) : 355 - 358.

Vega, S. G.; Guzman, P.; Garcia, L.; Espinosa, J. and Nava, C. (1988): Sperm shape abnormality and urine mutagenicity in mice treated with niclosamide. Mutat. Res., 204 (2) : 269 - 276.

Voller, A.; Bidwell, D.E. and Bartlett, A. (1979): The enzyme Linked Immunosorbent Assay (ELISA). Zoological Society, London.

Jaffe, B.M. and Behrman, N.R. (1974): Methods of Hormone Radioimmunoassay. Academic Press, London.

Vrzgulovi, M.; Bire, J. and Vrzgula, L. (1995): The microscopic structure of the testes in breeding rams after 
experimental copper oxide intoxication from industrial emissions. Folia Veterinaria, 39: $101-106$.

WHO (1993): The control of schistosomiasis: second report of the WHO Expert Committee. WHO Technical Report
Series, 830. World Health Organization, Geneva.

WHO (2003): Niclosamide. Data Sheet on Pesticides No. 63. World Health Organization and Food and Agriculture Organization : 1 - 27.

\section{تأثير بعض مضادات القواقع على الكفاءة اتناسلية فى الفئران}

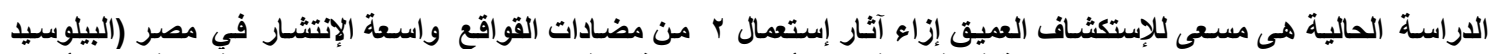

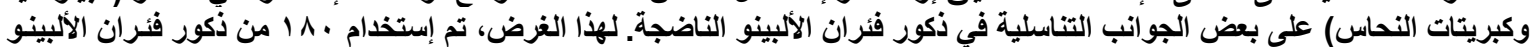

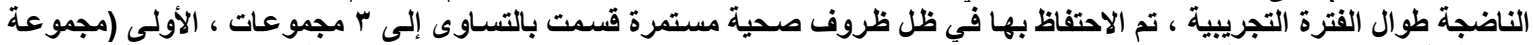

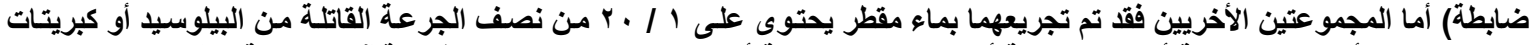

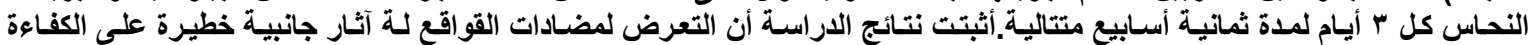

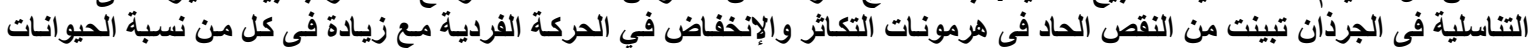

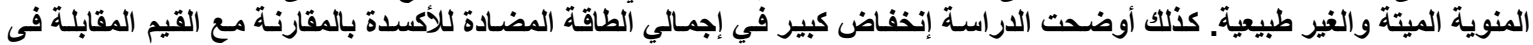
المجموعة الضابطة. 